\title{
Natural Killer Cell and Glucocorticoid Deficiency with DNA Repair Defect
}

National Cancer Institute

\section{Source}

National Cancer Institute. Natural Killer Cell and Glucocorticoid Deficiency with DNA

Repair Defect. NCI Thesaurus. Code C123729.

A cong enital condition characterized by growth retardation, a decreased number of NK cells, glucocorticoid deficiency, and increased chromosome breakage, associated with mutation(s) in the MCM4 gene. 